\title{
MOLECULAR PHYLOGENY OF THREE OCTOPODID SPECIES FROM THE MEDITERRANEAN WATER, EGYPT
}

\author{
Abdalla M. Ibrahim ${ }^{1}$, Waheed M. Emam ${ }^{1}$, \\ Ellen Kenchington ${ }^{2}$ and Tarek G. Ali $^{1}$ \\ 1- Zoology Dept., Fac. Sci., Ain Shams University, Cairo, Egypt . \\ 2- Dept. of Fisheries \& Oceans, P.O. Box 550, Halifax, N.S., CANADA.
}

\section{ABSTRACT}

The DNA sequence of a 612-nucleotide fragment of the mitochondrial 1 cytochrome oxidase subunit III gene (CO III) from three Mediterranean octopodid species namely: Octopus vulgaris, $O$. macropus and Eledonmoschata, has been determined. The perecentage of nucleotide composition of A/T,C/G was investigated. The CO III gene in these species revealed higher values of $A+T$ against moderately low $\mathrm{G}+\mathrm{C}$ content. COMPARE computer software program was applied for determining the percentage of pairwise sequence differences $(\mathrm{P})$ between different species.

The results of the present work are discussed with those previously obtained for $O$. bimaculoides, O. bimaculatus, O. dofleini, $O$. rubescens, O. cyanea and O. californicus. They indicated that O.vulgaris and $O$. macropus belong to the DNA distance-based tree of $O$. bimaculatus, while E. moschata is an outgroup in relation to the other species.

\section{INTRODUCTION}

Most of the previous attempts to identify and classify cephalopods had been based on external morphology, internal structure, behaviour and skin patterning (Robson, 1925, 1929 \& 1932; Packard \& Hochberg ,1977; Voss \& Voss ,1983 ; Hanlon,1988). The phylogenetic relationship between Octopus vulgaris and $O$. mimus using mitochondrial 16S ، RNA was studied by Warnke et al. ( 2002 ). The same author in 2004 discussed the relationship within species group surrounding $O$. vulgaris as indicated from mitochondrial DNA nucleotide sequences.

These taxonomic treatments intended to use similarities and differences between related species to produce the current classification 
of coleoid cephalopods which is similar to Naef's (1923) reconstruction of ancestor-descendent relationships. The phylogenetic relationships among living cephalopods are not yet fully understood due to the lack of necessary information on many species (Boyle, 1983).

Although, the monophyletic origin of many genera of the modern cephalopods was known (Voss, 1977), the genus Octopus contains about 200 species (Hochberg et al., 1992) of which less than 50 have been described in detail (Sosa et al., 1995). The octopodid classifications have been traditionally, and are currently based on few readily apparent characters. Voight (1993) used cladistic analysis of characters that have been contributed to octopodid classifications. She indicated that the octopodid subfamilies are paraphyletic and they cannot be held to share evolutionary histories, although they have been defined on comparatively clear differences. Sosa et al. (1995) undertook phylogentic analysis on six Octopus species from North Pacific and provided guidance in the current debate on the DNA sequence of the mitochondrial cytochrome oxidase subunit III gene (CO III).

The present work aims to study the molecular phylogenetic relationship among three species of Octopus from Alexandria waters on the Mediterranean Sea. This includes analysis of DNA sequence of a 612 nucleotide fragment of the mitochondrial CO III gene for each octopodid species. The sequences of DNA for the present species were compared to that of 6 North Pacific species using PAUP computer software (Swofford, 1993). The data on these 6 species, of Octopus were retrieved from the sequence bank, senfank. So, this study aimed to provide a basic information for molecular phylogeny and one octopodid species to be compared with other molluscan groups.

\section{1) Molecular phylogeny}

\section{MATERIAL AND METHODS}

Specimens of Octopus vulgaris, O. macropus and Eledone moschata were collected from the Mediterranean water adjacent to Alexandria, Egypt, by using bottom trawler nets. They were taken alive to the Lab in large plastic vessels with fresh sea water. Tissue samples of their arms and mantle were preserved in absolute alcohol until the DNA was extracted.

For extraction of DNA, the tissue samples were cut into small pieces of about $0.5 \mathrm{~cm}$ in length, and kept in tubes to which a Tris base 
and EDTA (TE) were added and left for 30 minutes. Another change of TE solution was done. Tissues were further cut into smaller pieces. $0.6 \mathrm{ml}$ lysis buffer (100 mM EDTA), $24 \mu \mathrm{l} 20 \%$ sodium dodecylsulfate (SDS) and $15 \mu \mathrm{l}$ Proteinase $\mathrm{K}(20 \mathrm{mg} / \mathrm{ml})$ were respectively added and kept at $55^{\circ} \mathrm{C}$ overnight. $280 \mu \mathrm{l}$ saturated $\mathrm{NaCl}$ were added, vortex $5 \mathrm{~min}$, then spin for $15 \mathrm{~min}$. (1400 r/min). $0.5 \mathrm{ml}$ chloroform was added to the supernatent (DNA), vortex $2 \mathrm{~min}$. and spin for $1 \mathrm{~min}$. The solution was poured into screw top tube, then $1 \mathrm{ml}$ isopropanol was added to the supernatent and mixed well by hand. Precipitation took place in $-20^{\circ} \mathrm{C}$ freezer for 1 hour, followed by spinning for 5-10 mins. $100 \mu \mathrm{l} 0.3$ $\mathrm{MNaCH}_{3} \mathrm{COO}$ was added to dissolve pellets. Then $250 \mu$ cold $100 \%$ ethanol (spin 5-10 min) was added. The liquid was pipetted off, followed by adding $20 \mu \mathrm{l} 70 \%$ ethanol and spin for $2 \mathrm{~min}$ for clearing DNA. The supernatent was sucked off and the tubes were covered with Kim wipes then $100 \mu \mathrm{l}$ of sterile double dist $\mathrm{H}_{2} \mathrm{O}$ was added.

DNA was amplified using small dilutions of DNA as follows: 1/50 DNA was taken, $287 \mu \mathrm{l}$ of double dist $\mathrm{H}_{2} \mathrm{O}$, 3.5 $\mu \mathrm{l}$ of Tag polymerase, $14 \mu \mathrm{l}$ of 16 SAR primer (CoIII: 3,5TAATTATAGATGAATGGC-3!), $14 \mu \mathrm{l}$ of 16 SBR primer (CoIII: 5'5'TATAATGGTTTACGATGAG-3') and $3.5 \mu \mathrm{l}$ dNTPs were added. DNA amplification was performed in PCR thermal cycler (Coy Tempcycler II) apparatus. The previous solutions were the PCR Cocktail. $23 \mu \mathrm{l}$ of this cocktail was taken in PCR tube, $2 \mu \mathrm{l}$ of diluted DNA 1/50 and 2 drops of light mineral oil were added for each PCR tube. The temperature profile for PCR includes: denaturation at $94^{\circ} \mathrm{C}$ for 30 seconds, annealing at $40^{\circ} \mathrm{C}$ for 45 seconds and extension $72^{\circ} \mathrm{C}$ for $1 \mathrm{~min}$.

Before DNA sequencing was attempted, PCR products were pretreated with Exonuclease I for removing excess polymerase and Alkaline phosphatase for removing excess d NTPs.

For sequencing of DNA, the label mixture [Reacting buffer (RX), Dithiothreitol (DTT), Label $\mathrm{S}^{35}$, dATP, DNA polymerase] was prepared, $7.5 \mu \mathrm{l}$ of this mixture was added to $10 \mu \mathrm{l}$ of each tube of PCR product, followed by - step solution. DNA sequencing step was performed using PCR sequencing Kit from USB, USA.

For running in gel, Long Ranger Taurine Gel and Buffer solution (Tris base, taurine dolid, EDTA and $\mathrm{ddH}_{2} \mathrm{O}$ were prepared. Before running, the gel was prerun for (10-15 $\mathrm{min}$ ) and of samples denaturate for 
(2-5 min) at $72^{\circ} \mathrm{C}$. Running in gel at (1600 volts, $40 \mathrm{~mA}$ and 60 Watts) for 2 hours.

For autoradiography, the gel was transferred onto Whatman 3MM filter paper covered by plastic warp. The Gel was dried under vaccum at $70^{\circ} \mathrm{C}$ to $80^{\circ} \mathrm{C}$ for $30 \mathrm{~min}$. Then exposed to Kodak X-ray film. Reading of the film were taken after 2-3 days. Data was introduced into Computer in PAUP program (Sowofford, 1993) to get results.

The aligned DNA sequence of the cytochrome oxidase subunit III gene (COIII) from Octopus vulgaris, O. macropus and Eledone moschata was compared to that of 6 North Pacific species. The COIII coding region was analyzed for Jukes-Cantor corrected substitutions per nucleotide at non synonymous and synonymous sites using COMPARE Computer software programm.

The DNA sequence of the preserved tissue samples were done at Dalhousie University, Canada.

\section{RESULTS}

\section{Sequence Comparisons}

The aligned DNA sequences of CO III for O. vulgaris and Eledone moschata compared to that of the North Pacific species is shown in Fig. 1 using PAUP program (Sowofford, 1993). The COIII gene sequences for the present octopodid species as well as the other 6 pacific ones are $\mathrm{A}+\mathrm{T}$ rich, with a very low $\mathrm{G}+\mathrm{C}$ content, particularly in the third position of codons. Data in Table 1 indicate that the percentage pairwise COIII sequence differences $(\mathrm{P})$ between $O$. vulgaris and both $O$. macropus and Eledone moschata were $18.4 \%$ \& 20.5\%, respectively. However, percentage pairwises were about $1.6 \%$ \& $18.8 \%$ between $O$. macropus and both of $O$. vulgaris and E. moschata respectively, and those between E. moschata and both of O.vulgaris and O. macropus were about. 1.8\%The percentage nucleotide substitutions were maximal at the third codon position as shown from P-value in Table 2. Morever, the pairwise comparison of total nucleotide transmission (v), Tamura-Nei (TN), ratio of transion to transversion (ns/nv) and the total value of amino acids (aa) for O. vulgaris, O. macropus and E. moschata is shown in Table 2. The nucleotide change pathways for the observed differences between octopodid CO III fragments and the values of total nucleotide transversion in all codon positions (between $\mathrm{A} / \mathrm{T}$ and $\mathrm{C} / \mathrm{G}$ ) were about $2 \%$ 
MOLECULAR PHYLOGENY OF THREE OCTOPODID 167 SPECIES FROM THE MEDITERRANEAN WATER, EGYPT

between $E$. moschata and both $O$. vulgaris and $O$. macropus, respectively (Table 3). 


\section{Nucleotide composition}

The nucleotide composition for the three octopodid species is shown in Table 4. It is clear that the percentage of $A / T, C / G$ varied according to their position in nucleotides for each of the three investigated species. For example, for $O$. macropus $\mathrm{T}$ ratios were $33.2 \%$, $43.2 \%$ \& $37.8 \%$ in position $1,2 \& 3$ respectively, while they were $34.6 \%$, $42.2 \%$ \& $45.9 \%$, respectively for $O$. vulgaris.

\section{Distance Trees}

The neighbour joining phylogeney for the Octopus COIII genes, based on transversions only, is presented in Fig. 2. The confidence limits on the nodes determined in trees were obtained using 500 bootstrap replicates. The DNA distance-based trees clearly indicate that $O$. vulgaris falls with clade of $O$. bimaculoides and $O$. bimaculatus with high bootstrap value (99\%), while O. macropus showed a relatively smaller value (60\%). On the other hand, E. moschata was found to have a separate branch of the tree. These results were also related to that obtained for amino acid parismony (Fig. 3).

\section{DISCUSSION}

In the present study, the phylogenetic relationships for Octopus vulgaris, O. macropus and Eledone moschata from the Mediterranean Sea were investigated. The results were compared with those obtained for 6 North Pacific Octopuses namely: O. dofelini, O. californicus, $O$. bimaculoides, O. bimaculatus, O. rubescens and O. cyanea (Sosa and Brian, 1995).

The neighbour-joining phylogeny for the Octopus COIlI genes based on transversions indicated that there were two major clades. The first clade includes $O$. vulgaris, O. macropus, O. bimaculatus, $O$. bimaculoides, $O$. rubescens, and $O$. cyanea, while the second one includes $O$. dofelini and $O$. californicus.

In decapods, each family is supported by strong bootstrap value and thus it was considered to be monophyletic, but there was a lack of resolution between the different families (Bonnaud, 1997). The data of the present study suggested that E. moschata may be considered as an outgroup in relation to the other species under investigation.

The phylogenetic analysis on a 784 - bp fragment of 82 actin gene sequences of 44 coleoid cephalopod taxa obtained from genomic southern blot analysis was studicd by David et al . ( 2000 )

Warnkre et al. ( 2004 ) discussed Sequence Y mithochandnal 
DNA in some other octopuses and built another phylogey tree. Protein maximum-like hood trees indicated that $O$. vulgaris, O. macropus, $O$. cyanea and $O$. rubescens belong to the same clade in different relatives.

\section{ACKNOWLEDGMENT}

The authors thank Dr. Donald Stewart from Zourous Lab, Dalhousie University, CANADA for his help during the study.

\section{REFERENCES}

Boyle, P. R. (Ed) (1983). “Cephalopod life cycles”. pp. 1-8, Academic press. London.

David, B.; Carlini , K. ; Reece, S. and Graves, J. E. ( 2000 ). Actin gene and evolution, phylogeny of coleoid cephalopods. Molec. Biol. and Evo. 170:1353 - 1370.

Hanlon, R. T. (1988). Behavioral and body patterning characters useful in taxonomy and field identification of cephalopods. Malacologia, 29: 247-264.

Hochberg, F. G.; Nixon, M. and Toll, R. B. (1992). Octopoda. In Larval and Juvenile Cephalopods: A Manual for their Identification. (Sweeney et al., Eds.), Smith Contrib. Zool., 513: 213-279.

Naef, A. (1923). Cephalopoda. Part 1, vol. 1 , Fascicle II, in Fauna and Flora of the Bay of Naples 35. Israel program for scientific translations, Jerusalem, pp. 293-879. 
Packard, A. and Hochberg, F. G. (1977). Skin patterning in Octopus and other genera. Symp. Zool. Soc. London, 38: 191-231.

Robson, G. C. (1929). A monograph of the Recent Cephalopoda. Part 1 the Octopodinae. Brit. Mus. Nat. Hist, 236 pp.

Robson, G. C. (1932). Amonograph of the Recent Cephalopoda. Part 2. Octopodidae exclusive of Octopodinae. Brit. Mus. Nat. Hist, 359 pp.

Robson, G. C. (1925). The deep Sea Octopoda. Proceeding of the Zool. Soc. Lond, pp. 1323-1356.

Sosa, K. B., and Brian, H. (1995). The Molecular Phylogeny o Five Eastern North Pacific Octopus species, Molecu. Phyl. Evol., June 4 (2): 163-174.

Swofford, O. L. (1993). PAUP: Phylogenetic analysis using Parsimony, Version 3.1.1. Computer Program distributed the Illinois Natural History Survey. Champaign, Illinois.

Voight, R. (1993). A cladistic Reassessment of Octopodid Classification. Malacologia, 35(2): 343-349.

Voss, G. L. (1977). Present status and new trends in Cephalopod systematic. Symp. Zool. Soc. London, 38: 49-60. 
Voss, N. A. and Voss, R. S. (1983). Phylogenetic relationships in the Cephalopod family Cranchiidae (Aegopida). Malacologia, 23(2): 397-426.

Warake , H.; Söller ,R.; Blohm, D.; Saint - paul,U. ( 2002 ). Assessment of the phylogenetic relationship between Octopus vulgaris ( cuvier , 1797and O.mimus Gould ,1852 ) using mitochomdrial 16s RNA ., Abh . Geol. A 57i 401- 405.

Warnke , L .; Söller , R.; Blohm, D.; Saint Paul , U . ( 2004 ). A new look at geographic and phylogenetic relationships \& Octopus vulgaris : indications from mitochondrial DNA sequances, of. Zool . syst. E vol. Researeh, 42: 306 - 312 . 